\title{
THE U.S. LONG-HAUL TRUCKING INDUSTRY THROUGH THE LENS OF FREI'S SERVICE MODEL
}

\author{
Andrew S. Griffith \\ Iona College • New Rochelle, NY
}

\section{$\overline{\text { ABSTRACT }}$}

This paper examines the irregular route, long-haul segment of the U.S. trucking industry through the lens of Frei's (2008) service model. Firms in this industry often offer too many services. Frei's model predicts firms that do not focus on the market niches that are best met by their core expertise are at risk of losing their profitable niches to competitors. To address two key industry problems identified through the lens of this service model, a modification to the industry's billing model and a minimum guaranteed daily wage for drivers are proposed.

\section{INTRODUCTION}

Frei (2008) describes a service model that firms need to follow in order to survive on a long-term basis. The elements of this service model are the offering, the funding process, and managing the employee and customer systems. Failing in any one of these four areas can lead to the demise of a firm.

The purpose of this paper is to apply Frei's (2008) service model to the irregular route, long-haul segment of the United States trucking industry. This segment was selected due to its volatility and normally disorganized, fragmented condition (Jin, Swanson, Waller, \& Ozment, 2017; Page, 2017) whereas the regular route component of this industry appears to be better organized than its counterpart (Belzer, 1995). A discussion of the irregular route, long-haul US trucking industry through the lens of Frei's (2008) service model follows.

\section{THE U.S. INTERSTATE TRUCKING INDUSTRY FIRM TURNOVER}

Manatayev (2004) observed that third party logistics services were experiencing commoditization since deregulation. Commoditization of an industry is accomplished by transforming the industry into a buyer's market, which includes reduced margins, additional services, and increased competition in the form of many firms. More than 1000 firms in the U.S. third-party logistics industry as of 2003 is sufficient evidence of this industry's fragmented state. 
Similar to the third-party logistics industry, the interstate trucking industry in the U.S. is also fragmented. The Federal Motor Carrier Safety Administration (FMCSA) (2016) reported on October 28, 2016 that 512,145 firms were registered with interstate carrier authority. On September 27, 2019, the FMCSA(2019) disclosed that 569,946 registered firms had interstate carrier authority. Further analysis of these FMCSA disclosures reveals that at least 118,641 firms (23.17\% of October 2016's disclosure) ceased operations and more than 183,128 firms (32.13\% of September 2019's disclosure) began operations during the 35 months between disclosures. Part of the increase in interstate firms during this time can be explained by a movement within the industry to require contractors to possess their own operating authority if they want to lease to certain established interstate trucking firms (for example, see https://www.drive4freymiller.com/own-authority/). Nevertheless, the large quantity of firms within this industry indicates that the industry is flooded with capacity and the buyers can dictate the terms. The failure rate within the industry is an indicator of margins being low and the large quantity of new entrants to the industry suggests that barriers to entry (human capital, financial capital, etc.) are low.

\section{The Offering}

According to Frei's (2008) service model, a firm's offering of a service requires that the service must meet the customer's needs, be excellent, convenient, and friendly for the customer. Firms often encounter challenges created by flaws in the execution of the delivery of the offered service. Frei compares the service design process with the design phase of a product. As a result, the design phase for both categories should be conceptually the same and incorporate strategic planning.

A key flaw found in many firms' service offerings involves attempting to offer too many services to their customers with the idealistic and often naïve approach of attempting to be a customer's sole service provider (Frei, 2008). Stone (2009) argues that the services offered by a firm should depend on that firm's priorities and not its desire to meet all customers' needs or resolve all of their problems. In other words, firms should specialize in their offerings.

Harrison-Walker (2009, p. 107) points out the "confused perception [of a firm] in consumers' minds" is often a direct result of firms attempting to offer a broad array of services to its customers. She advocates for firms to concentrate on what they do well to effectively position themselves within the marketplace. This allows each firm to create a perception of uniqueness within its market niche.

Firms that "attempt to be all things to all people begin to struggle when upstart 
competitors... start picking off profitable niches" (Frei, 2008, p. 78). Some firms elect to selectively cover profitable market niches and ignore the rest of the market. Broadly focused firms that experience poaching of their profitable niches often do not realize or react to the activity until it is too late because they are unable to focus on their primary market.

The trucking industry has historically been tightly regulated. Pettus and Munoz (2007) concluded that firms within this industry were unable to reach any level of optimal resource utilization during its period of regulation. When the industry was deregulated in the 1980s, the industry became more fragmented and disorganized but still remains heavily burdened with regulations (Belzer, 1995; Winebrake et al., 2015). The modern period of deregulation permitted the industry's customers to exploit its many weaknesses (Guo, Lim, Rodrigues, \& Zhu, 2006) while simultaneously eliminating trucking firms that were inefficient or irresponsible with their resources (Pettus \& Munoz, 2007).

Trucking firms that tend to do well within their markets usually focus on the services that they execute best (Jin, et al., 2017). As a result, they normally do not offer a wide array of services to their customers. In other words, they specialize instead of attempting to be the supermarket of the trucking industry. Those that attempt to offer a wide array of services frequently compromise their brand positioning efforts.

In an effort to counteract this kind of negative effect on their brands and still offer many services to their customers, some firms in this industry formed strategic alliances (Pettus \& Munoz, 2007). Strategic alliances allow firms to pool their freight and maximize the utilization of their resources (Nowak, Ergun, \& White, 2008; Pettus \& Munoz, 2007; Prabhu, D, Surekha, Holla, \& Patel, 2008). Another advantage to these alliances it is allows their customers to have access to a supermarket of sorts for their trucking needs (Nowak, et al., 2008). This technique also allows the industry an opportunity to create an image of cooperation and present itself as being less disorganized and fragmented.

\section{The Funding Mechanism}

The funding mechanism involves more than the simple collection of funds from customers. Frei (2008) identifies four areas that could improve funding: quality collections from customers, balancing operational savings with value-added services, strategic spending, and shifting work to the customer. It entails providing quality service to the customer so that a discount is not needed to entice the customer to do business with the firm. 
Because people tend to focus primarily on the short-term results instead of the long-term benefits (Boles, Barksdale, \& Johnson, 1997), decision-makers in trucking firms will often take any load that will keep their equipment occupied instead of locating loads that are in the best long-term interests of their firms (Min $\&$ Lambert, 2002). When this situation arises, customers can and do exploit the apparent weaknesses of the short-term focused trucking firms. If a customer is capable of routinely exploiting this scenario, that customer may not conduct any business with a firm unless an opportunity to exploit such a weakness exists (e.g. discounted rates in exchange for keeping the equipment busy).

Such scenarios produce a power imbalance in the customer-vendor relationship (Essabbar, Zrikem, \& Zolghadri, 2016; Nyaga, Lynch, Marshall, \& Ambrose, 2013). Such an imbalance can lead to a vendor becoming inappropriately dependent on a customer (Essabbar, et al., 2016). For example, a common but adverse practice within the trucking industry involves the efforts of some customers to lengthen the payment cycle to the trucking firms. This practice further strengthens a customer's power imbalance over a trucking firm and permits that customer to dictate the payment terms and rates and even the utilization of the trucking firm's equipment.

In an effort to minimize a customer's ability to exploit the trucking firms' need for cash, France requires its trucking firms to be paid within 30 days (Barrot, 2016). The United States government requires its agencies to pay small businesses "within 15 days instead of 30 days" and the EU prohibits payment terms beyond 60 days without a formal written agreement (Barrot, 2016, p. 1977).

Another example of an adverse customer dependent relationship is when the trucking firm is or has become cash poor and starts to factor its receivables (Barrot, 2016). Firms that need cash quickly to address short-term funding issues will often sell their receivables under recourse conditions or negotiate even lower rates with the debtor customer that is delaying payment in exchange for an immediate cash inflow. Some firms will offer a version of factoring by agreeing to pay a reduced rate in exchange for making the contractual payment within a shorter period of time (such as 20 days within invoice date) instead of the contracted rate with a customerimposed longer payment period (such as 60 or more days).

Cash hungry organizations will often elect to defer maintenance and training expenditures now to use these funds elsewhere (Calderon, Wang, \& Conrad, 2012; Kaganova, 2010). A consequence of this practice is a shorter life span of the equipment, which requires more funds to repair or replace the equipment later (Vanier, 2001). Operational savings is created by extending the lifespan of existing equipment and not by replacing that equipment more frequently. Properly 
planned maintenance activities and regular training of the equipment operators and maintenance personnel to maintain their skills extends the lifespan of equipment and translates to operational savings in the long run (Kolman, 2011).

This segment of the trucking industry routinely fails to hold the customer responsible for its work. Truck drivers are routinely required to load and unload the customer's freight and they often wait extended amounts of time for their customers to take delivery (Belzer \& Sedo, 2017). The time spent waiting and loading or unloading often results in little or no compensation for the drivers and, in some cases, the drivers are required to pay a third party or the customer to do it (Belzer $\&$ Sedo, 2017; Min \& Lambert, 2002). The carrier is often forced to provide low cost freight storage for the customer. In this situation, the customer succeeds in transferring its work to the carrier. Collectively, this segment could eliminate some of its inefficiencies if the customer was required to load and unload its freight. More importantly, carriers need to do a better job of holding the customer financially responsible for the excessive time spent under a load. Carriers should not be a cheap alternative to traditional freight storage but a more expensive alternative.

\section{The Employee Management System}

A proper employment management system enables employees to perform to the best of their abilities (Frei, 2008). This system covers all aspects of the employee experience at a firm: from appropriate and reasonable compensation packages to proper training, job/employee matching, as well as hiring and retention practices. A key aspect of this is ensuring that the employee is sufficiently challenged and that the employee's skills are properly utilized to meet both the needs of the firm and the employee. Failure to do so makes it difficult to meet the commitments to customers.

The trucking industry has a traditional emphasis of focusing on building capacity and staffing its capacity to the maximum without focusing on maximizing the utilization of its resources before adding more capacity. Evidence of this is born by frequent claims of an industry-wide or firm-specific driver shortage (Min \& Lambert, 2002).

Additional evidence of the industry's lack of utilization of its resources is found in the high turnover rates among its drivers (Lemay, Taylor, \& Turner, 1993; Nyaga, et al., 2013). Drivers in the irregular route, long-haul trucking industry are often paid on a per mile basis (Belzer \& Sedo, 2017). If they are not receiving a sufficient quantity of regular paid miles or overall compensation to meet their own financial needs, they will move to an employer that promises them better financial 
results (Lemay, et al., 1993; Min \& Lambert, 2002).

Variances in the paid mileage and overall compensation of the drivers often are a direct function of the scheduling practices of the firm (Belzer \& Sedo, 2017). Customers that insist on scheduling pickup and delivery times with excessive days built into these loads are using a trucking company's equipment as free or low rent storage facilities. For example, a normal three-day trip might be scheduled in a way that requires the driver to spend six days with the load. This hurts the utilization of the equipment and the driver's compensation. Trucking firms can minimize some of the financial consequences of this practice if they schedule the pickup and delivery times in a manner that minimizes the driver's and equipment's idle time.

From the driver's perspective, he has little control over when a customer decides to load the truck and when it is willing to take delivery of the product. The time that the driver spends waiting on the load often results in minimal compensation that amounts to nothing more than a token, after-tax, value that might cover most of the cost of his meals (Belzer \& Sedo, 2017). This practice contributes unnecessarily to high turnover rates in the industry (Lemay, et al., 1993; Min \& Lambert, 2002).

A properly managed firm will maximize the utilization of its employees without suppressing the compensation packages of its employees. In other words, a productive trucking firm will keep its drivers from sitting idle without earning a reasonable daily wage. A poorly managed firm will either schedule its drivers with excessive travel time or will allow the customer to utilize the equipment and driver without proper compensation for the time, resources, and risk involved. Ultimately, inefficient utilization of a firm's resources (including its employees) results in less revenues, less contribution margin (to cover fixed costs and profits), and reduced profits or increased losses (Katz \& Shapiro, 1994).

\section{The Customer Management System}

Frei (2008) considers the customer management system to be the focal point of the business activity that simultaneously meets the needs of the customers and the firm. To accomplish this, firms often establish different priority levels for their customers. Those who represent a significant volume of business or a critical area of a firm's business activity would take priority over those who represent a minor or insignificant portion of the firm's business.

Some firms attempt to train their customers and employees by invoking a system of rewards and punishments for the customers' behavior (Frei, 2008). These rewards encourage specific behaviors that benefit the firm and the punishments 
discourage behaviors that are contrary to the firm's mission. One motivation for such a system is a quest to reduce customer variability (Frei, 2006).

During the age of regulation, trucking firms were permitted to operate in very inefficient manners. In fact, firms were unable to operate at optimal efficiency because of the regulatory environment (Pettus \& Munoz, 2007). Deregulation removed the safeguards that ensured the survival of many inefficient firms and allowed customers to disregard the needs of the trucking industry to be more efficient with its resources.

After deregulation, many firms in the trucking industry attempted to cater to every customer's desires by taking any and all loads that fit their short-term focus of equipment utilization regardless of profitability. Some of this is clearly a function of economic agency issues - meaning that a firm's agents were operating in their own best interests instead of the best interests of their employers (Jensen \& Meckling, 1976; Mitnick, 1973). As a result, these firms were often obligated to transport product at rates significantly below the actual costs to move these loads. Obviously, this arrangement was not in the best long-term interests of firms but keeping the equipment occupied was in the short-term interests of the firm's agents.

Large customers have exploited the deregulated and fragmented trucking industry to obtain lower rates and extended low-cost use of its equipment. Much of this was accomplished through the use of carrier assignment models. This allowed customers to efficiently identify the carriers that would provide the desired service at the lowest possible rates (Guo, et al., 2006).

As fuel costs rose significantly after 2001, trucking firms began to react and take a stand against hauling product for inadequate rates and inefficient use of their resources. This translated to an industry-wide renegotiation of freight transportation terms including expanding the practice of a cost sharing provision, called a fuel surcharge, based on the market rate of fuel (Winebrake, et al., 2015). Additional provisions negotiated during this effort included additional rates for occupying the equipment for extended timeframes (such as excessive loading or unloading time and layover charges), providing additional services (such as expedited delivery), and customer error (failure to comply with the shipping terms or errors in loading trucks). Trucking firms should extend this process by billing their customers not just on a per-mile or agreed rate-per-load basis (with a fuel surcharge hedging variable) but to include a per-day rate that covers the trucking firm's cost per day for the equipment (and the normal daily wages of the assigned drivers) while under that load.

Along with this improvement of the equipment utilization, the industry made some adjustments to its compensation package to acquire and retain the better drivers (Min \& Lambert, 2002). This resulted in significant improvements to the rates in 
the industry's compensation model but these changes remain inadequate as drivers still are not compensated adequately for the time they work (Belzer \& Sedo, 2017). Drivers should be compensated in a way that ensures the needs of the trucking firms and the customers are better met.

One approach to this is to provide the driver with a guaranteed minimum daily wage for every day spent away from home. This minimum guaranteed daily wage would have to be set high enough to ensure that the driver can pay for his meals and continue to meet reasonable financial obligations. This may be accomplished by setting this minimum guaranteed daily wage rate at $300 \%$ of the IRS recognized per diem rate for those subject to DOT hours of service. The $300 \%$ multiplier is intended to ensure that each driver has some funds available after paying for their daily expenses away from home and taxes to meet non-driving financial obligations while keeping the calculation simple and easy for firms to implement and manage.

\section{CONCLUSION}

Frei's (2008) service model is a compelling argument for firms to specialize in their industries instead of "[attempting] to be all things to all people" (p. 78). She advocates that firms should focus on the market segment(s) that match their core expertise and ignore the other areas of their industry. Firms that attempt to offer too many services tend to be distracted from the areas of their core expertise and that creates opportunity for their competitors.

Because of the fragmented condition of the U.S. irregular route, longhaul trucking industry, firms in this industry that offer a wide range of services to customers will be prone to having their profitable market niches exploited by competitors who are willing to focus on these niches and ignore the other market segments. Underlying this condition is an industry that has great difficulty with employee management, customer management, and its funding and service offering processes. This highlights that the traditional ways of conducting business in this industry are inefficient, insufficient, and economically harmful to the firms and those working within the industry. The firms that excel in this industry manage Frei's (2008) service model better than their competition. 


\section{REFERENCES}

Barrot, J. N. (2016). Trade Credit and Industry Dynamics: Evidence from Trucking Firms. The Journal of Finance, 71(5), pp. 1975-2016. doi:10.1111/jofi.12371

Belzer, M. H. (1995). Collective Bargaining after Deregulation: Do the Teamsters Still Count? Industrial and Labor Relations Review, 48(4), pp. 636-655. doi: $10.2307 / 2524348$

Belzer, M. H., \& Sedo, S. A. (2017). Why do long distance truck drivers work extremely long hours? The Economic and Labour Relations Review, pp. 1-21. doi:10.1177/1035304617728440

Boles, J. S., Barksdale, H. C., \& Johnson, J. T. (1997). Business relationships: an examination of the effects of buyer-salesperson relationships on customer retention and willingness to refer and recommend. The Journal of Business \& Industrial Marketing, 12(3/4), pp. 253-264.

Calderon, T. G., Wang, L., \& Conrad, E. J. (2012). Material Internal Control Weakness Reporting Since the Sarbanes-Oxley Act. The CPA Journal, 82(8), pp. 20-25.

Essabbar, D., Zrikem, M., \& Zolghadri, M. (2016). Power imbalance in collaboration relationships. International Journal of Supply and Operations Management, 2(4), pp. 1021-1034.

Federal Motor Carrier Safety Administration. (2016). Motor Carrier Census Information. U.S. Department of Transportation. Retrieved from https:// ai.fmcsa.dot.gov/SMS/Tools/Downloads.aspx.

Federal Motor Carrier Safety Administration. (2019). Motor Carrier Census Information. U.S. Department of Transportation Retrieved from https://ai.fmcsa. dot.gov/SMS/Tools/Downloads.aspx.

Frei, F. X. (2006). Breaking the trade-off between efficiency and service. Harvard Business Review, 84(11), pp. 92-101. Retrieved from https://hbr.org/2006/11/ breaking-the-trade-off-between-efficiency-and-service.

Frei, F. X. (2008). The four things a service business must get right. Harvard Business Review, 86(4), pp. 70-80. Retrieved from https://hbr.org/2008/04/thefour-things-a-service-business-must-get-right

Guo, Y., Lim, A., Rodrigues, B., \& Zhu, Y. (2006). Carrier assignment models in transportation procurement. The Journal of the Operational Research Society, 57(12), pp. 1472-1481. doi:10.1057/palgrave.jors.2602131

Harrison-Walker, L. J. (2009). Strategic positioning in higher education. Academy of Educational Leadership Journal, 13(1), pp. 103-111. 
Jensen, M. C., \& Meckling, W. H. (1976). Theory of the firm: Managerial behavior, agency costs and ownership structure. Journal of Financial Economics, 3(4), pp. 305-360. doi:10.1016/0304-405X(76)90026-X

Jin, Y. H., Swanson, D., Waller, M., \& Ozment, J. (2017). To survive and thrive under hypercompetition: an exploratory analysis of the influence of strategic purity on truckload motor-carrier financial performance. Transportation Journal, 56(1), pp. 1-34.

Kaganova, O. (2010). Government Property Assets in the Wake of the Dual Crisis in Public Finance and Real Estate: An Opportunity to Do Better Going Forward? Real Estate Issues, 35(3), pp. 31-41.

Katz, M. L., \& Shapiro, C. (1994). Systems Competition and Network Effects. The Journal of Economic Perspectives (1986-1998), 8(2), p 93. doi:10.1257/ jep.8.2.93

Kolman, D. A. (2011). Maintenance Outlook Report. Fleet Maintenance, 15(10), pp. 8-10,12-14,16-22,24-25.

Lemay, S. A., Taylor, G. S., \& Turner, G. B. (1993). Driver turnover and management policy: A survey of truckload irregular route motor carriers. Transportation Journal, 33(2), p 15-21.

Manatayev, Y. Y. (2004). Commoditization of the third party logistics industry (Master of Engineering in Logistics). Massachusetts Institute of Technology, Cambridge, MA.

Min, H., \& Lambert, T. (2002). Truck driver shortage revisited. Transportation Journal, 42(2), pp. 5-16.

Mitnick, B. M. (1973) Fiduciary rationality and public policy: The theory of agency and some consequences. Paper presented at the 1973 Annual Meeting of the American Political Science Association, New Orleans, LA. https://papers.ssrn. com/sol3/papers.cfm?abstract_id=1020859

Nowak, M., Ergun, O., \& White, C. C., III. (2008). Pickup and delivery with split loads. Transportation Science, 42(1), pp. 32-43. doi:10.1287/trsc.1070.0207

Nyaga, G. N., Lynch, D. F., Marshall, D., \& Ambrose, E. (2013). Power Asymmetry, Adaptation and Collaboration in Dyadic Relationships Involving a Powerful Partner. Journal of Supply Chain Management, 49(3), pp. 42-65.

Page, P. (2017, Apr 10). Business News: Truckers Knight And Swift To Merge. Wall Street Journal.

Pettus, M. L., \& Munoz, J. M. (2007). Resource-based value creation: Experiences from the U. S. deregulated trucking industry. Competition Forum, 5(1), pp. 253259 . 
Prabhu, B. V., D, R., Surekha, A., Holla, A. J., \& Patel, K. M. (2008). Value stream mapping of truck operations: A case study. South Asian Journal of Management, 15(2), pp. 107-115.

Stone, R. D. (2009). Achieving results with a performance-centered design framework. Performance Improvement, 48(5), pp. 37-44. doi:10.1002/pfi.20077

Vanier, D. J. (2001). Why Industry Needs Asset Management Tools. Journal of Computing in Civil Engineering, 15(1), 35-43. doi:10.1061/(ASCE)08873801(2001)15:1(35)

Winebrake, J. J., Green, E. H., Comer, B., Li, C., Froman, S., \& Shelby, M. (2015). Fuel price elasticities in the U.S. combination trucking sector. Transportation Research Part D: Transport and Environment, 38(Supplement C), pp. 166-177. doi:10.1016/j.trd.2015.04.006

\section{BIOGRAPHICAL SKETCH OF AUTHOR}

Andrew S. Griffith, DBA, EA, CPA, CMA, CIA, CFE, CRMA, is an Associate Professor of Accounting at Iona College (USA), where he teaches undergraduate thesis research courses in the Honors Program and graduate accounting courses. $\mathrm{He}$ is a former Assistant Director of the Honors Program and a former Chair of the Human Subjects/Institutional Review Board at Iona College. His research doctorate in accounting is from Nova Southeastern University. 